\title{
Role of Alkaline Constituent On Properties And Microstructure of Crushed Rock Based Alkali- Activated Material For Low Strength Applications
}

\section{Teewara SUWAN}

Chiang Mai University

Peerapong Jitsangiam ( $\nabla$ peerapong@eng.cmu.ac.th )

Chiang Mai University https://orcid.org/0000-0002-7569-9173

Hemwadee THONGCHUA

Chiang Mai University

Ubolluk RATTANASAK

Burapha University

Weerachart TANGCHIRAPAT

King Mongkut's University of Technology Thonburi

Phattharachai MAICHIN

Chiang Mai University

\section{Research}

Keywords: Alkali-activated material, Cement-stabilized pavement, Crushed rock, Low strength construction material, Microstructure

Posted Date: August 17th, 2021

DOI: https://doi.org/10.21203/rs.3.rs-772525/v1

License: (c) (1) This work is licensed under a Creative Commons Attribution 4.0 International License. Read Full License 


\section{Abstract}

A more sustainable and innovative cementitious material would serve green construction for the future and could yield tremendous leverage to the problem of $\mathrm{CO}_{2}$ emissions. Alkali-activated materials (AAMs) could be an alternative binder for relatively low strength construction and rehabilitation as a cement replacement material. The lower strength requirements, e.g., road construction materials, compared to other applications could ease any difficulties with AAM production. For this study, crushed rock (CR) was used as the prime material of a precursor. A laboratory investigation of mechanical properties was performed in conjunction with XRF, XRD, and SEM techniques. The results showed that CR-based AAM with an optimum mixture of $5 \mathrm{M}$ of $\mathrm{NaOH}$ concentration, an SS/SH ratio of 1.0, and a liquid-to-binder (L/B) ratio of 0.5 could be used a part of relatively low strength materials. At this ratio, the paste samples

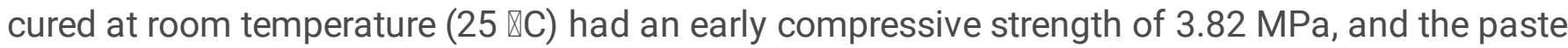
samples cured at $60 \mathbb{} \mathrm{C}$ had an early compressive strength of $6.45 \mathrm{MPa}$. The results passed the target compressive strength of cementitious construction materials such as construction block (3.0 MPa-7.0 $\mathrm{MPa}$ ) and cement-treated base (CTB) for pavement (2.1 MPa-5.5 MPa).

\section{Introduction}

Recently, with increased attention to the global warming era, the roadway construction sector has been pressured to be more sustainable to develop clean and green technology. Innovative and sustainable materials based on the concept of alkali-activated material (AAM) have recently been introduced to the sector. They are in the early stages of investigation [1-3]. AAM is the broadest classification of binder systems derived by a chemical reaction of alkaline sources (in solid or dissolved form) with any prime materials $[4,5]$. This prime material can be a calcium silicate compound in ordinary Portland cement or a more aluminosilicate-rich precursor (e.g., fly ash, bottom ash, metallurgical slag, naturally pozzolan). AAM is believed to be a green construction material for the future because it produces much less $\mathrm{CO}_{2}$ emission than ordinary Portland cement (OPC). OPC is the most frequently used construction material, and it is the most popular stabilizing agent. AAM could yield sufficient strength and other satisfying manners resulting from the chemical reaction between an alkaline solution and a solid aluminosilicate precursor [6-12]. However, alkali-activated cement technology has apparent limitations. Heat curing is a primary factor of the complete chemical reaction processes to be a significant problem. The difficulty of heat curing hinders its acceptance as an OPC replacement, among other applications. Adopting an AAM with low strength for specific purposes, e.g., unfired bricks or roadway applications, was the challenge in developing a new and green construction material. This study gave a preliminary introduction to relatively low strength AAM as an environmentally friendly road construction material to replace the consumption of OPC. There could help to minimize global $\mathrm{CO}_{2}$ emissions by the cement production industry.

In the manufacturing industry, cement production emits approximately $7 \%$ of global $\mathrm{CO}_{2}$ emissions [13]. Every ton of cement production produces approximately one ton of $\mathrm{CO}_{2}$ into the atmosphere [14]. OPC was the most widely used material for almost all kinds of structures. For mitigating the use of OPC, 
cement substitute materials were introduced [15-17], and AAMs were currently introduced as having the potential to replace OPC with less $\mathrm{CO}_{2}$ emissions. It was claimed that AAMs emitted more than $80 \%$ less $\mathrm{CO}_{2}$ compared to OPC [18]. The AAM can be synthesized by mixing by-product materials (e.g., fly ash, bottom ash, or furnace slag) with alkaline solutions (e.g., sodium hydroxide and sodium silicate) [19, 20]. Figure 1 shows the synthesis process of AAM based on the view of this study. The main composition of AAM, based on calcium content, is calcium aluminosilicate hydrate (C-A-S-H). It has a layer structure similar to calcium silicate hydrate (C-S-H) and sodium aluminosilicate hydrate (N-A-S-H), a two-to-threedimensional structure of Si-O-Al in the matrices [20, 21]. Alkali-activation has two phases, high-calcium alkali-activated and low-calcium alkali-activated, otherwise known as "geopolymers" [22].

The targeted applications of this relatively low strength AAM may be applied to the roadway with crushed rock as a precursor. Road pavement has an average design life of about 15-30 years [23]. Hence, the number of roads that require rehabilitation and reconstruction has grown to meet the high demand for transporting goods [24] and people under the current economic circumstances. Therefore, reconstructing and rehabilitating road pavement in an environmentally sustainable and cost-effective manner is an engineering challenge. Typically, road pavement requires a relatively low-strength material compared to other civil engineering structures. To improve the mechanical properties of road base materials, cement stabilization through in-situ pavement recycling was the most popular technique. In this approach, a small amount of cement was added to existing pavement materials; there was no transportation of new road pavement construction materials [25]. In-situ cementitious rehabilitation (i.e., pavement recycling with cement stabilization for road pavements as shown in Fig. 2 ) is considered a cheaper ( 35 to $50 \%$ of the cost of reconstruction) and potentially environmentally sustainable solution because it recycles existing pavement materials [26]. It was found that the compressive strength of cement-stabilized base materials increases with higher cement content $[27,28]$. Currently, OPC is used for more than $80 \%$ of road rehabilitation activities worldwide [27]. Although pavement rehabilitation uses only about 2 to $8 \%$ (by weight) of OPC compared to 10 to $16 \%$ for concrete, the amount of concrete utilized would be relatively small compared to the pavements to be rehabilitated. When in-situ pavement rehabilitation is more widely used, as predicted from the recent growth of the road network worldwide, OPC use for this purpose could vastly increase (estimated to be about 150 tons $\mathrm{km}^{-1}$ ) [29]. This higher amount of cement use would cause relatively sharp increases in $\mathrm{CO}_{2}$ emissions owing to cement production. Therefore, alkali-activated stabilizers (binders) for in-situ pavement rehabilitation as a potential environmentally and structurally sustainable solution should be cleverly engineered.

The primary raw material in this study is crushed rock (CR) which is a calcium-rich material. The presence of calcium in the AAM system can provide the basis for gaining strength at room temperature [30-32]. This study has the ultimate goal to explore the possibility of AAM as cementitious material using CR as source material with no other active precursors (e.g., fly ash). The influential factors of AAM for road stabilized were investigated through the compressive strength. Thus, the results introduce the possible use of the crushed rock-based AAM with relatively low strength and more environmentally friendly construction material. 
In this study, CR, which is generally used as a road base material, was used as the source material of AAM production. Physical properties of AAM were studied, including the setting times, flowability, and compressive strength. Results were compared with the requirements values for roadway materials. Besides, chemical compositions, morphology, and microstructure of AAM were performed, using X-ray fluorescence (XRF), X-ray diffraction (XRD), and a scanning electron microscope (SEM), respectively.

\section{Materials}

\subsection{Raw Materials}

CR was used as a raw material for AAM production and was obtained from the Chiang Mai local quarry of Sila Mae Tha Co., Ltd., Thailand. It was crushed into smaller sizes and sieved with the mesh sieve number of 100 ( $0.15 \mathrm{~mm}$ opening), obtaining a fine material. The chemical composition of the CR was shown in Table 1 , analyzed by XRF. Calcium oxide $(\mathrm{CaO})$ and silica $\left(\mathrm{SiO}_{2}\right)$ are the main oxide compounds in CR. Minor compounds consist of alumina $\left(\mathrm{Al}_{2} \mathrm{O}_{3}\right)$ and ferrous oxide $\left(\mathrm{Fe}_{2} \mathrm{O}_{3}\right)$.

Table 1

Chemical Compositions of Crushed Rock

\begin{tabular}{|lllllll|}
\hline Chemical Composition & $\mathrm{Al}_{2} \mathrm{O}_{3}$ & $\mathrm{SiO}_{2}$ & $\mathrm{~K}_{2} \mathrm{O}$ & $\mathrm{CaO}$ & $\mathrm{MnO}$ & $\mathrm{Fe}_{2} \mathrm{O}_{3}$ \\
\hline $\mathrm{CR}(\% \mathrm{w} / \mathrm{w})$ & 8.06 & 21.99 & 4.39 & 59.53 & 0.28 & 5.74 \\
\hline
\end{tabular}

\subsection{Alkaline activators}

Alkaline materials used in this study were sodium hydroxide $(\mathrm{NaOH})$ and sodium silicate $\left(\mathrm{Na}_{2} \mathrm{SiO}_{3}\right)$. $\mathrm{NaOH}$ solution was prepared by dissolving sodium hydroxide pellets in purified water, obtaining the concentrations of 3,5 , and 8 molars $(M)$. The solution was allowed to cool down to room temperature. Sodium silicate solution was received from Union Science Co., Ltd., Thailand, with sodium oxide $\left(\mathrm{Na}_{2} \mathrm{O}\right)$ and silicon oxide $\left(\mathrm{SiO}_{2}\right)$ contents of $16.3 \%$ and $34.2 \%$ by weight.

\section{Experimental Procedures}

Figure 3 shows the framework and methodology of this study. Firstly, fine-grained CR was analyzed the chemical composition and morphology using XRF and XRD analyses. The mixture design of CR-AAM was presented in Table 2. The main parameters for the study were the $\mathrm{NaOH}$ concentration and the mass ratio of sodium silicate-to-sodium hydroxide (SS/SH). Two curing conditions were studied: room temperature (RT) curing and oven curing at $60 \mathbb{} \mathrm{C}$ for 24 hours. For later curing conditions, specimens were kept at RT after heat curing until the test age. In the mixing process, all constituents were homogeneously mixed in a mixing bowl until an AAM paste was achieved. Setting time [33] and flow test [34] were performed on the fresh paste. 
Table 2

Constituents of Crushed rock-based geopolymer cement

\begin{tabular}{|c|c|c|c|c|c|}
\hline $\mathrm{NaOH}$ (Molar) & Crushed rock (g) & SS/SH ratio & L/B ratio & $\begin{array}{l}\mathrm{NaOH} \\
\text { sol. (g) }\end{array}$ & $\begin{array}{l}\mathrm{Na}_{2} \mathrm{SiO}_{3} \\
\text { sol. (g) }\end{array}$ \\
\hline & 1500 & 0.67 & 0.45 & 404.2 & 270.8 \\
\hline & & 0.67 & 0.50 & 449.1 & 300.9 \\
\hline & & 0.67 & 0.55 & 494.0 & 331.0 \\
\hline & & 1.00 & 0.45 & 337.5 & 337.5 \\
\hline \multirow[t]{9}{*}{3} & & 1.00 & 0.50 & 375.0 & 375.0 \\
\hline & & 1.00 & 0.55 & 412.5 & 412.5 \\
\hline & & 1.50 & 0.45 & 270.0 & 405.0 \\
\hline & & 1.50 & 0.50 & 300.0 & 450.0 \\
\hline & & 1.50 & 0.55 & 330.0 & 495.0 \\
\hline & 1500 & 0.67 & 0.45 & 404.2 & 270.8 \\
\hline & & 0.67 & 0.50 & 449.1 & 300.9 \\
\hline & & 0.67 & 0.55 & 494.0 & 331.0 \\
\hline & & 1.00 & 0.45 & 337.5 & 337.5 \\
\hline \multirow[t]{9}{*}{5} & & 1.00 & 0.50 & 375.0 & 375.0 \\
\hline & & 1.00 & 0.55 & 412.5 & 412.5 \\
\hline & & 1.50 & 0.45 & 270.0 & 405.0 \\
\hline & & 1.50 & 0.50 & 300.0 & 450.0 \\
\hline & & 1.50 & 0.55 & 330.0 & 495.0 \\
\hline & 1500 & 0.67 & 0.45 & 404.2 & 270.8 \\
\hline & & 0.67 & 0.50 & 449.1 & 300.9 \\
\hline & & 0.67 & 0.55 & 494.0 & 331.0 \\
\hline & & 1.00 & 0.45 & 337.5 & 337.5 \\
\hline \multirow[t]{4}{*}{8} & & 1.00 & 0.50 & 375.0 & 375.0 \\
\hline & & 1.00 & 0.55 & 412.5 & 412.5 \\
\hline & & 1.50 & 0.45 & 270.0 & 405.0 \\
\hline & & 1.50 & 0.50 & 300.0 & 450.0 \\
\hline
\end{tabular}




\begin{tabular}{|lccccc|}
\hline $\mathrm{NaOH}$ (Molar) & Crushed rock (g) & $\mathrm{SS} / \mathrm{SH}$ ratio & $\mathrm{L} / \mathrm{B}$ ratio & $\mathrm{NaOH}$ & $\mathrm{Na}_{2} \mathrm{SiO}_{3}$ \\
& & & sol. (g) & sol. (g) \\
\hline & 1.50 & 0.55 & 330.0 & 495.0 \\
\hline Remark: SS/SH $=0.55$ for setting time and flow test and SS/SH $=0.50$ for compressive strength test. \\
\hline
\end{tabular}

Also, the paste was cast into $40 \mathrm{~mm} \times 40 \mathrm{~mm} \times 160 \mathrm{~mm}$ prism molds [35] and left overnight before demolding. After demolding, the samples were wrapped with a plastic film and separately cured with two conditions. Tests were performed on the hardened specimens at testing ages of 3 and 28 days, including XRD, SEM, and compressive strength [35].

\section{Results And Discussion}

\subsection{Setting times and flowability}

Generally, in the construction fieldwork, the concrete mixture should be operated for a reasonable time, not a fast set and not a long set. This property allows the concrete mixture to have a time gap for transportation, pouring, and compacting, while it should be de-formed within a specific period to catch on the working schedule [36]. Setting time is the first step to verify the setting behavior of the fresh paste, which commonly depends on the chemical reaction of the raw materials [37]. The mixtures of the CRAAM paste were prepared with a constant liquid-to-binder (L/B) ratio of 0.55 for the setting time and flow test. SS/SH ratios were used at 0.67 and 1.50 , while the $\mathrm{NaOH}$ concentrations were 3,5 , and $8 \mathrm{M}$. Results were shown in Fig. 4. The initial setting time of the paste complied with the standard of OPC, of not less than 45 minutes for $3 \mathrm{M}$ and $5 \mathrm{M} \mathrm{NaOH}$ usage. A rapid setting was observed with $8 \mathrm{M} \mathrm{NaOH}$ usage since the high concentration reacted quickly with the calcium compound in the system. The trend of setting times shows that an increase in the SS/SH ratio from 0.67 to 1.50 delayed the formation of the pastes due to the appearance of many silicon ions from sodium silicate [38]. It has been reported that the higher $\mathrm{SS} / \mathrm{SH}$ ratio could delay the initial setting time and affect the strength development after the hardening process $[39,40]$.

The use of higher $\mathrm{NaOH}$ concentration led to more leaching of silica and alumina from the CR. It could react rapidly with the calcium compound in the $\mathrm{CR}$, providing calcium hydroxide $(\mathrm{C}-\mathrm{H})$, calcium silicate hydrate (C-S-H), and calcium aluminosilicate hydrated (C-A-S-H) for fast setting behavior [6].

Flowability is the ability of freshly mixed cement or concrete to move or operate in practical works. In concrete operation, the flow value is known as "workability." In general, high water content provides excellent workability, which is preferred for on-site applications. However, too much water decreases the compressive strength and causes more air voids in the hardened cement structure [41, 42]. Consequently, a flow test was carried out to determine the appropriate mixtures and constituents for crushed rock-based 
alkali-activated pastes. The mixes for the flow test were the same as those used for investigating setting times.

The results were in line with previous research studies $[43,44]$. The flow values decreased when the concentration of $\mathrm{NaOH}$ increased from 3 to $8 \mathrm{M}$. The reason is directly related to the overall water content in the mixtures, as higher $\mathrm{NaOH}$ concentrations commonly provide less flowability. Besides, $\mathrm{C}-\mathrm{H}, \mathrm{C}-\mathrm{S}-\mathrm{H}$, and C-A-S-H were formed in the mixture. In contrast, the sodium silicate solution's high viscosity was also caused by coagulated mixtures, leading to low flow values. Therefore, the higher SS/SH ratio of 1.50 resulted in lower flow values than that of 0.67 . The summary results of the setting times and flowability of CR-AAM are presented in Fig. 4.

\subsection{Setting times and flowability}

\subsubsection{Effects of $\mathrm{NaOH}$ concentrations and curing conditions}

The effects of $\mathrm{NaOH}$ concentrations on the strength of AAM were analyzed. An L/B ratio of 0.50 and an $\mathrm{SS} / \mathrm{SH}$ ratio of 1.00 were set for curing the AAM at RT and $60^{\circ} \mathrm{C}$. The results show that the strength of all mixtures increased with the longer curing time, as shown in Fig. 5 . There was approximately $40 \%$ and $20 \%$ increment, respectively, for $5 \mathrm{M}$ and $8 \mathrm{M} \mathrm{NaOH}$ for both curing conditions. The chemical reactions of high calcium-alkaline-activated material occurred very quickly since its early age $[45,46]$. Strength varied in the range of 3.82 to $5.40 \mathrm{MPa}$ for RT curing and 6.45 to $9.40 \mathrm{MPa}$ for oven curing. Therefore, when considering compressive strength itself, the CR-AAM of this study preparing with $5 \mathrm{M}$ and $8 \mathrm{M} \mathrm{NaOH}$ can be used in some relatively low strength applications, e.g., such as road construction material.

SEM images in Fig. 6 show the microstructures of CR-AAM in both RT and oven curing conditions preparing with an $\mathrm{SS} / \mathrm{SH}$ ratio of 1.0 and $\mathrm{L} / \mathrm{B}$ ratio of 0.5 . It can be observed that a structural formation can be rapidly achieved at a very early age owing to the alkali reaction of high calcium content in CR. Microstructure patterns of both curing conditions were slightly different. The firm and dense microstructures were observed in oven-cured AAM, implying more thorough geopolymerization in the heat curing environment.

Effects of $\mathrm{NaOH}$ concentration on the microstructure of AAM with oven curing were carried out. Results are shown in Fig. 7. From the SEM images, $\mathrm{NaOH}$ concentration directly affected the microstructure of the final products. With $8 \mathrm{M} \mathrm{NaOH}$, a firm and compact texture of the AAM was achieved, resulting in satisfying compressive strength. On the other hand, with low $\mathrm{NaOH}$ concentrations of $3 \mathrm{M}$ and $5 \mathrm{M}$, the matrices were quite loose with scattered voids and microcavities, leading to the low compressive strength of AAM.

From the SEM results, it can be summarized that an appropriate range of $\mathrm{NaOH}$ concentration for CRAAM is $5 \mathrm{M}$ to $8 \mathrm{M}$ because the required strength was achieved at both curing conditions. However, using 
a $5 \mathrm{M} \mathrm{NaOH}$ in mixture yields cost savings and greater workability when fresh paste for low-strength applications is produced.

\subsubsection{Effects of sodium silicate-to-sodium hydroxide ratios and curing conditions}

The effects of SS/SH ratios of $0.67,1.00$, and 1.50 on compressive strength and microstructures of CRAAM were studied. $5 \mathrm{M} \mathrm{NaOH}$ and L/B ratio of 0.50 were set for this study. Results are shown in Fig. 8. A similar trend was observed compared with the effect of $\mathrm{NaOH}$ concentrations (Fig. 5). The strength of all the mixtures was developed by the curing time, and high strength achievement occurred with oven curing at $60^{\circ} \mathrm{C}$.

With a constant $5 \mathrm{M} \mathrm{NaOH}$, a higher SS/SH ratio provided an additional source of silica (Si) besides controlling the binding activity of the cementitious systems. The compressive strength of the AAMs cured at room temperature for 28 days increased from 4.79 MPa to 5.18 MPa when the SS/SH ratio increased from 0.67 to 1.00 , whereas the compressive strength of AAMs cured at $60{ }^{\circ} \mathrm{C}$ for 28 days rose from 5.55 $\mathrm{MPa}$ to $9.40 \mathrm{MPa}$. However, the compressive strength fell-at both curing conditions-when the SS/SH ratio was 1.50 (Fig. 8). It can be explained that a higher ratio of SS/SH commonly gains an inert characteristic of the solution. A viscous sodium silicate could retard the chemical reaction after mixing because of insufficient water in the system. In addition, the formation of silica gel and the existence of excess sodium silicate in this system could lower strength.

Figure 9 shows SEM images of the AAMs cured at room temperature with different SS/SH ratios. Although there was no significant difference in visual screening observations, at SS/SH ratios of 1.00 and 1.50 , the microstructures of the mixtures seem to be more compact. They have denser matrices than when the SS/SH ratio is 0.67 . Thus, it can be concluded that the optimal SS/SH ratio for AAM is 1.00 . The reasons are that, at this mixture proportion, the cement can achieve maximum compressive strength (at 5.18 MPa and 9.40 MPa for room temperature and oven curing, respectively at 28 days) and also have sufficient flowability for practical work applications. Lower cost was also obtained due to the reduction use of sodium silicate solution.

\subsubsection{Effects of liquid alkaline-to-binder ratios and curing regimes}

The liquid-to-binder (L/B) ratio is an essential factor for AAM synthesis as it indicates the amount of overall water in the system. The L/B ratio is partially similar to the water-to-cement (w/c) ratio in Portland cement production. However, the amount of water in liquid alkaline $(\mathrm{L})$ must be re-calculated from the concentrated solution before comparing it to the water $(w)$ in any cementitious mixture. A water-to-solid $(\mathrm{w} / \mathrm{s})$ ratio is the total mass of water in the sodium hydroxide solution and the sodium silicate solution compared to the mass of all solids from crushed-rock, micro-pearl sodium hydroxide, and sodium silicate solid. The $\mathrm{w} / \mathrm{s}$ ratios of all mixtures are presented in Table 3. 
Table 3

The w/s ratio of various alkaline dosages in CR-based geopolymer cement

\begin{tabular}{|c|c|c|c|c|}
\hline \multirow{2}{*}{$\begin{array}{l}\text { SS/SH } \\
\text { ratio }\end{array}$} & \multirow{2}{*}{$\begin{array}{l}\mathrm{L} / \mathrm{B} \\
\text { ratio }\end{array}$} & \multicolumn{3}{|c|}{ Water-to-solid (w/s) ratio } \\
\hline & & $\mathrm{NaOH} 3 \mathrm{M}$ & $\mathrm{NaOH} 5 \mathrm{M}$ & $\mathrm{NaOH} 8 \mathrm{M}$ \\
\hline \multirow[t]{3}{*}{0.67} & 0.45 & 0.295 & 0.276 & 0.254 \\
\hline & 0.50 & 0.324 & 0.303 & 0.278 \\
\hline & 0.55 & 0.352 & 0.329 & 0.301 \\
\hline \multirow[t]{3}{*}{1.00} & 0.45 & 0.275 & 0.260 & 0.241 \\
\hline & 0.50 & 0.301 & 0.284 & 0.264 \\
\hline & 0.55 & 0.327 & 0.308 & 0.286 \\
\hline \multirow[t]{3}{*}{1.50} & 0.45 & 0.255 & 0.243 & 0.229 \\
\hline & 0.50 & 0.279 & 0.266 & 0.250 \\
\hline & 0.55 & 0.302 & 0.288 & 0.271 \\
\hline
\end{tabular}

The water-to-solid (w/s) ratios are plotted against liquid alkaline-to-binder (L/B) ratios in Fig. 10. Any properties of the final hardened products influenced by the amount of water can be observed: (i) the w/s ratios decrease when the $\mathrm{NaOH}$ concentration increases, (ii) the w/s ratios decrease when the SS/SH ratio increases, and (iii) the $\mathrm{w} / \mathrm{s}$ ratios increase when the L/B ratio increases.

The effect of L/B ratios of $0.45,0.50$, and 0.55 on the mechanical properties of CR-AAM material was studied. $\mathrm{A} \mathrm{NaOH}$ concentration of $5 \mathrm{M}$ and an $\mathrm{SS} / \mathrm{SH}$ ratio of 1.00 was set for curing mixtures at room temperature and $60^{\circ} \mathrm{C}$ in the oven. It should be noted that the compressive strength of all the mixtures also developed by the passing time, as shown in Fig. 11.

The highest compressive strength was achieved at room curing temperature with an L/B ratio of 0.45 when aged for three days (4.48 $\mathrm{MPa})$ and 28 days $(6.88 \mathrm{MPa})$. The compressive strength levels were very close to each other when the L/B ratio was 0.50 and 0.55 , and they were lower than when the L/B ratio was 0.45 . Also, the trend of compressive strength for mixtures cured at $60^{\circ} \mathrm{C}$ was significantly different. The mixture obtained the highest compressive strength with an L/B ratio of 0.50 , followed by 0.45 and 0.55 .

From these results, it can be concluded that the maximum strength was obtained for curing at room temperature when the L/B ratio was 0.45 . On the other hand, the greatest compressive strength was achieved in oven curing when the L/B ratio was 0.50 . In this case, the additional water content can compensate for some evaporation from the heat curing process, leading to the maximum compressive strength when cured for a more extended period. However, water in the AAM material is mainly on controlling the alkaline activator's concentration. In different cases, low alkaline solution concentration 
with a suitable high L/B ratio may achieve superior properties due to felicitous conditions for the hardened products. With an optimal $\mathrm{NaOH}$ concentration of $5 \mathrm{M}$ and an SS/SH ratio of 1.00 , the water content ( $\mathrm{w} / \mathrm{s}$ ratio) of CR-AAM material should be between 0.26 and 0.28 (equivalent to an L/B ratio between 0.45 and 0.50 ) to achieve both setting behavior and workability as seen in Sect. 4.1.

\subsection{XRD analysis}

XRD analysis was carried out to investigate the structural formations and chemical compounds of both original crushed-rock material and AAM. $5 \mathrm{M} \mathrm{NaOH}$ with an L/B ratio of 0.50 and SS/SH ratio of 1.0 were set for this study. XRD pattern of original crushed rock reveals the structure formation of quartz $(\mathrm{Q})$ and calcite (C) in the forms of $\mathrm{SiO}_{2}$ and $\mathrm{CaCO}_{3}$, respectively, while aluminum oxide (Al) refers to a crystalline structure of $\mathrm{Al}_{2} \mathrm{O}_{3}$. It is noted that a sharp peak of calcite located at 29.4 two-theta degrees refers to the rampant amount of calcium content in that crushed-rock material. Besides, Portlandite $(\mathrm{P})$ or $\mathrm{Ca}(\mathrm{OH})_{2}$ were found in both curing conditions due to the reaction of calcium compounds and hydroxide ion $(\mathrm{OH}-)$ in the systems. The quartz (Q) and aluminum compound (Al) in the original crushed rock at 26.6 and 43.2 two-theta degrees could be transformed to Kyanite $(\mathrm{K})$, which is an aluminosilicate compound $\left(\mathrm{Al}_{2} \mathrm{O}_{5} \mathrm{Si}\right)$ in the structure. The graphs mainly show the sharp peaks, which indicate the formation of crystallinity. However, small humps of those geopolymer mixtures also were observed between 28 and 34 two-theta degrees, indicating the partial formation of amorphous phases of the alkali-activated structure (Fig. 12).

In addition, the comparative XRD patterns of AAMs with both curing conditions at 28 days were also carried out, as shown in Fig. 13 and Fig. 14. There was no significant difference in XRD results between curing at room temperature and $60^{\circ} \mathrm{C}$; the patterns are similar. Nevertheless, oven curing should be recalled that higher strengths were achieved than by room temperature curing. The reason is that oven curing provided more geopolymerization with a more robust polymeric chain and dense matrices.

Generally, a higher concentration of $\mathrm{NaOH}$ could provide a higher dissolution rate for alkali-activated pastes to re-polymerize their structure [21]. More intensity of kyanite $(K)$ at 26.7 two-theta degrees was observed with the $\mathrm{NaOH}$ concentrations of $8 \mathrm{M}, 5 \mathrm{M}$, and $3 \mathrm{M}$. Similar characteristics were observed at the peak around 29.5 two-theta degree of calcium silicate hydrated (C-S-H, C') as mixtures with higher $\mathrm{NaOH}$ concentrations gained more intensity from XRD analysis. In some cases, the crystalline form of calcium aluminosilicate hydrated (C-A-S-H) was also detected from $\mathrm{CaO}, \mathrm{Al}_{2} \mathrm{O}_{3}$, and $\mathrm{SiO}_{2}$ in the parent raw material. Furthermore, a high curing temperature (i.e., $60^{\circ} \mathrm{C}$ ) can increase the formation rate of both $\mathrm{C}-\mathrm{S}-\mathrm{H}$ and C-A-S-H, resulting in the early development of compressive strength [47-51]. The chemical formula, from the XRD database, of C-S-H (Tobermorite) and C-A-S-H is $\mathrm{Ca}_{5} \mathrm{Si}_{6} \mathrm{O}_{16}(\mathrm{OH})_{2} \cdot 4 \mathrm{H}_{2} \mathrm{O}$ and $\mathrm{CaAl}_{2} \mathrm{Si}_{2} \mathrm{O}_{8} \cdot 4\left(\mathrm{H}_{2} \mathrm{O}\right)$, respectively.

The Peak area of the XRD pattern was also calculated using the Origin® program; a 2-theta degree in the range of 25 to 35 was selected as reaction products mainly occurred in this range. Results of peak area are shown in Table 4. It can be seen that peak area was increased with using of high $\mathrm{NaOH}$ concentration, it increases $10-20 \%$ of peak area comparing with that of $3 \mathrm{M} \mathrm{NaOH}$. Oven curing resulted in a higher 
peak area than RT curing, which heats activated more product formation. Results of peak area corresponded to that of compressive strength.

Table 4

Peak area of XRD pattern of AAMs (25-35 2-theta degree)

\begin{tabular}{|lllll|}
\hline NaOH concentration & \multicolumn{3}{l|}{ RT curing } & Oven curing \\
& Peak area (a.u.) & \% difference & Peak area (a.u.) & \% difference \\
\hline $3 \mathrm{M}$ & 3816 & 0 & 3944 & 0 \\
\hline $5 \mathrm{M}$ & 4205 & 10 & 4545 & 15 \\
\hline $8 \mathrm{M}$ & 4445 & 16 & 4743 & 20 \\
\hline
\end{tabular}

\section{Concluding Remarks}

This preliminary study on the properties and microstructures of CR-AAM was carried out to explore the opportunity to replace OPC and develop an alternative material for environmentally friendly construction material. The conclusions are these.

- The setting time of crushed-rock-based alkali-activated paste depends mainly on the concentration of $\mathrm{NaOH}$. Rapid setting occurred at a concentration of $8 \mathrm{M}$, as the high concentration reacted quickly with calcium in the system. Flow values decreased when the concentration of $\mathrm{NaOH}$ increased from $3 \mathrm{M}$ to $8 \mathrm{M}$ as less water was present. The same results occurred when a higher SS/SH ratio was applied.

- The compressive strength of crushed rock-based alkali-activated paste was developed by the passing time. Moreover, it was clear that heat curing (oven curing at $60^{\circ} \mathrm{C}$ ) leads to higher compressive strength than curing at room (ambient) temperature. However, the room curing process could achieve the low-strength alkaline-activated cement used for low-strength applications, e.g., roadway, pavement, or construction block.

- $\mathrm{NaOH}$ concentrations between $5 \mathrm{M}$ and $8 \mathrm{M}$ gave the materials satisfying strength. However, a $5 \mathrm{M}$ concentration is preferable from setting time, flowability, and costs. An SS/SH ratio of 1.0 provided the highest compressive strength and most flowability. For room curing, an L/B ratio of 0.45 yielded the best maximum strength value for practical work applications. The best L/B ratio for oven curing was 0.50 to compensate for evaporation during the heat curing process.

Overall, this preliminary investigation of crushed-rock-based AAM indicated that the best mixture had a $\mathrm{NaOH}$ concentration of $5 \mathrm{M}$, an SS/SH ratio of 1.0 , and an L/B ratio of 0.5 . With these parameters, paste cured at room temperature yielded an early compressive strength of $3.82 \mathrm{MPa}$, and paste cured at $60 \bowtie \mathrm{C}$ yielded an early compressive strength of $6.45 \mathrm{MPa}$. These results surpass the target compressive strength of Cement Treat Base for pavement or unfired brick, which is between $2.1 \mathrm{MPa}$ and $7.0 \mathrm{MPa}$. 


\section{Abbreviations}

AAM Alkali-activated materials

CTB Cement-treated base

CR Crushed rock

CR-AAM Crushed rock based alkali-activated material

L/B Liquid-to-binder ratio

OPC Ordinary Portland cement

RT Room temperature

SS/SH Sodium silicate-to-sodium hydroxide ratio

w/c Water-to-cement ratio

w/s Water-to-solid ratio

\section{Declarations}

\section{Availability of data and materials}

The datasets supporting the conclusions of this article are included within the article.

\section{Competing interests}

The authors declare they have no competing interests.

\section{Funding}

The second author wishes to express gratitude to the Thailand Research Fund (TRF) for the financial support of this project under "TRF Mid-Career Research Grant No. RSA 5980070." This research work was also partially supported by Chiang Mai University.

\section{Authors' contributions}

Suwan, T. and Jitsangiam, P. provided conceptual and technical guidance for all aspects of this research. Suwan, T., Jitsangiam, P., and Thongchua, $\mathrm{H}$. wrote the original draft manuscript. Thongchua, $\mathrm{H}$. and Maichin, P. analyzed the data. Rattanasak, U., Tangchirapat, W., and Maichin, P. reviewed and edited the manuscript. The authors read and approved the final manuscript.

\section{Acknowledgements}


The research team of the Civil Engineering Department in Chiang Mai University, King Mongkut's University of Technology Thonburi, Bangkok, and Burapha University are also gratefully acknowledged for providing overview guidance and valuable input to this work.

\section{References}

1. Phummiphan I, Horpibulsuk S, Rachan R, Arulrajah A, Shen SL, Chindaprasirt P. High calcium fly ash geopolymer stabilized lateritic soil and granulated blast furnace slag blends as a pavement base material. J Hazard Mater 2018;341:257-67. https://doi.org/10.1016/j.jhazmat.2017.07.067.

2. Tang N, Deng Z, Dai JG, Yang K, Chen C, Wang Q. Geopolymer as an additive of warm mix asphalt: Preparation and properties. J Clean Prod 2018;192:906-15. https://doi.org/10.1016/j.jclepro.2018.04.276.

3. Tenn N, Allou F, Petit C, Absi J, Rossignol S. Formulation of new materials based on geopolymer binders and different road aggregates. Ceram Int 2015;41:5812-20. https://doi.org/10.1016/j.ceramint.2015.01.010.

4. Fernández-Jiménez A, Monzó M, Vicent M, Barba A, Palomo A. Alkaline activation of metakaolin-fly ash mixtures: Obtain of Zeoceramics and Zeocements. Microporous Mesoporous Mater 2008;108:41-9. https://doi.org/10.1016/j.micromeso.2007.03.024.

5. Provis JL, Lukey GC, Van Deventer JSJ. Do Geopolymers Actually Contain Nanocrystalline Zeolites? A Reexamination of Existing Results. Chem Mater 2005;17:3075-85. https://doi.org/10.1021/cm050230i.

6. Shi C, Roy D, Krivenko P. Alkali-activated cements and concretes. UK: CRC press; 2006.

7. Davidovits J. Chemistry and applications. 2nd ed. Saint-Quentin, France: 2008.

8. Provis JL, van Deventer JSJ. Geopolymers: Structures, Processing, Properties and Industrial Applications. UK: Woodhead Publishing; 2009.

9. Provis JL, Duxson P, van Deventer JS. Alkali-activated binders to enhance the sustainability of concrete production. ASEAN Aust. Eng. Congr., Kuching, Malaysia: 2011.

10. Chindaprasirt $P$, Rattanasak $U$, Vongvoradit $P$, Jenjirapanya $S$. Thermal treatment and utilization of Alrich waste in high calcium fly ash geopolymeric materials. Int J Miner Metall Mater 2012;19:872-8.

11. Chindaprasirt P, Jenjirapanya S, Rattanasak U. Characterizations of FBC/PCC fly ash geopolymeric composites. Constr Build Mater 2014;66:72-8. https://doi.org/10.1016/j.conbuildmat.2014.05.067.

12. Eiamwijit M, Pachana K, Kaewpirom S, Rattanasak U, Chindaprasirt P. Comparative study on morphology of ground sub-bituminus FBC fly ash geopolymeric material. Adv Powder Technol 2015;26:1053-7. https://doi.org/10.1016/j.apt.2015.04.013.

13. Dezem V. Cement Produces More Pollution Than All the Trucks in the World 2019. https://www.bloomberg.com/news/articles/2019-06-23/green-cement-struggles-to-expand-marketas-pollution-focus-grows. 
14. Khongprom P, Suwanmanee U. Environmental benefits of the integrated alternative technologies of the Portland Cement Production: A case study in Thailand. Eng J 2017;21:15-27. https://doi.org/https://doi.org/10.4186/ej.2017.21.7.15.

15. Abdulmatin A, Khongpermgoson P, Jaturapitakkul C, Tangchirapat W. Use of Eco-Friendly Cementing Material in Concrete Made from Bottom Ash and Calcium Carbide Residue. Arab J Sci Eng 2018;43:1617-26. https://doi.org/10.1007/s13369-017-2685-x.

16. Rattanachu P, Toolkasikorn P, Tangchirapat W, Chindaprasirt P, Jaturapitakkul C. Performance of recycled aggregate concrete with rice husk ash as cement binder. Cem Concr Compos 2020;108:103533. https://doi.org/10.1016/j.cemconcomp.2020.103533.

17. Rattanashotinunt $C$, Tangchirapat $W$, Jaturapitakkul C, Cheewaket $T$, Chindaprasirt P. Investigation on the strength, chloride migration, and water permeability of eco-friendly concretes from industrial byproduct materials. J Clean Prod 2018;172:1691-8. https://doi.org/10.1016/j.jclepro.2017.12.044.

18. Turner LK, Collins FG. Carbon dioxide equivalent (CO2-e) emissions: A comparison between geopolymer and OPC cement concrete. Constr Build Mater 2013;43:125-30. https://doi.org/10.1016/j.conbuildmat.2013.01.023.

19. Davidovits J. Geopolymers: inorganic polymeric new materials. J Therm Anal Calorim 1991;37:1633-56. https://doi.org/https://doi.org/10.1007/BF01912193.

20. Suwan T, Fan M, Braimah N. Internal heat liberation and strength development of self-cured geopolymers in ambient curing conditions. Constr Build Mater 2016;114:297-306. https://doi.org/10.1016/j.conbuildmat.2016.03.197.

21. Si R, Guo S, Dai Q. Influence of calcium content on the atomic structure and phase formation of alkali-activated cement binder. J Am Ceram Soc 2019;102:1479-94. https://doi.org/10.1111/jace.15968.

22. Provis J, van Deventer J. Introduction and Scope. Alkali Act. Mater., Netherlands: Springer; 2014, p. 1-9.

23. Alderson A, Jameson G. Cemented materials characterisation: final report. Sydney, Australia: 2014.

24. Huan Y, Siripun K, Jitsangiam P, Nikraz H. A preliminary study on foamed bitumen stabilisation for Western Australian pavements. Sci Res Essays 2010.

25. Halsted GE, Adaska WS, McConnell WT. Guide to cement-modified soil (CMS). Skokie, Illinois, USA: Portland Cement Association; 2008.

26. Jitsangiam P, Boonserm K, Phenrat T, Chummuneerat S, Chindaprasirt P, Nikraz H. Recycled Concrete Aggregates in Roadways: Laboratory Examination of Self-Cementing Characteristics. J Mater Civ Eng 2015. https://doi.org/10.1061/(asce)mt.1943-5533.0001245.

27. Chakrabarti S, Kodikara JK, Pardo L. Survey results on stabilisation methods and performance of local government roads in Australia. Road Transp Res 2002;11:3-16.

28. Jitsangiam P, Suwan T, Pimraksa K, Sukontasukkul P, Chindaprasirt P. Challenge of adopting relatively low strength and self-cured geopolymer for road construction application: a review and 
primary laboratory study. Int J Pavement Eng 2019:1-15.

https://doi.org/10.1080/10298436.2019.1696967.

29. Sounthararajah A, Bui HH, Nguyen N, Jitsangiam P, Kodikara J. Early-Age Fatigue Damage Assessment of Cement-Treated Bases under Repetitive Heavy Traffic Loading. J Mater Civ Eng 2018;30. https://doi.org/10.1061/(asce)mt.1943-5533.0002250.

30. Chindaprasirt P, Paisitsrisawat P, Rattanasak U. Strength and resistance to sulfate and sulfuric acid of ground fluidized bed combustion fly ash-silica fume alkali-Activated composite. Adv Powder Technol 2014;25:1087-93. https://doi.org/10.1016/j.apt.2014.02.007.

31. Chindaprasirt P, Thaiwitcharoen S, Kaewpirom S, Rattanasak U. Controlling ettringite formation in FBC fly ash geopolymer concrete. Cem Concr Compos 2013;41:24-8. https://doi.org/10.1016/j.cemconcomp.2013.04.009.

32. Suwan T, Fan M. Influence of OPC replacement and manufacturing procedures on the properties of self-cured geopolymer. Constr Build Mater 2014;73:551-61.

https://doi.org/10.1016/j.conbuildmat.2014.09.065.

33. ASTM C191-08. Standard Test Methods for Time of Setting of Hydraulic Cement by Vicat Needle. ASTM Int West Conshohocken, PA 2008. https://doi.org/10.1520/C0191-08.

34. ASTM C230 / C230M-14. Standard Specification for Flow Table for Use in Tests of Hydraulic Cement. ASTM Int West Conshohocken, PA 2014. https://doi.org/10.1520/C0230_C0230M-14.

35. British Standard Institution. EN 196-1: 2016 Methods of Testing Cement - Part 1: Determination of Strength. Br Stand 2016.

36. Indian Roads Congress. Quality assurance handbook for rural roads. New Delhi, Indian: National Rural Roads Development Agency; 2016.

37. Taylor PC, Kosmatka SH, Voigt GF. Integrated materials and construction practices for concrete pavement: A state-of-the-practice manual. USA: Federal Highway Administration, Office of Pavement Technology; 2007.

38. Petermann JC, Saeed A, Hammons MI. Alkaline-activated geopolymers: A literature review. 2012. https://doi.org/10.21236/ada559113.

39. Hanjitsuwan S, Hunpratub S, Thongbai P, Maensiri S, Sata V, Chindaprasirt P. Effects of $\mathrm{NaOH}$ concentrations on physical and electrical properties of high calcium fly ash geopolymer paste. Cem Concr Compos 2014;45:9-14. https://doi.org/10.1016/j.cemconcomp.2013.09.012.

40. Siyal AA, Azizli KA, Man Z, Ullah H. Effects of Parameters on the Setting Time of Fly Ash Based Geopolymers Using Taguchi Method. Procedia Eng., vol. 148, Elsevier Ltd; 2016, p. 302-7. https://doi.org/10.1016/j.proeng.2016.06.624.

41. Bhandari N, Sherpa P, Shrestha P, Bhattarai P. Effect of water content on workability of concrete. Lalitpur, Nepal: 2019.

42. Jimma BE. Workability-integrated mixture proportioning method for pervious concrete. Clemson University, 2014. 
43. Laskar SM, Talukdar S. Preparation and tests for workability, compressive and bond strength of ultrafine slag based geopolymer as concrete repairing agent. Constr Build Mater 2017;154:176-90. https://doi.org/10.1016/j.conbuildmat.2017.07.187.

44. Yaseri S, Hajiaghaei G, Mohammadi F, Mahdikhani M, Farokhzad R. The role of synthesis parameters on the workability, setting and strength properties of binary binder based geopolymer paste. Constr Build Mater 2017;157:534-45. https://doi.org/10.1016/j.conbuildmat.2017.09.102.

45. Hardjito D, Wallah SE, Sumajouw DMJ, Rangan B V. Factors influencing the compressive strength of fly ash-based geopolymer concrete. Civ Eng Dimens 2004;6:88-93.

46. Hardjito D, Wallah SE, Sumajouw DMJ, Rangan BV. On the development of fly ash-based geopolymer concrete. ACI Mater J 2004;101:467-72. https://doi.org/10.14359/13485.

47. Dueramae S, Tangchirapat W, Sukontasukkul P, Chindaprasirt P, Jaturapitakkul C. Investigation of compressive strength and microstructures of activated cement free binder from fly ash-calcium carbide residue mixture. J Mater Res Technol 2019;8:4757-65.

https://doi.org/10.1016/j.jmrt.2019.08.022.

48. García-Lodeiro I, Fernández-Jiménez A, Palomo A. Variation in hybrid cements over time. Alkaline activation of fly ash-portland cement blends. Cem Concr Res 2013;52:112-22. https://doi.org/10.1016/j.cemconres.2013.03.022.

49. Guo X, Shi H, Wei X. Pore properties, inner chemical environment, and microstructure of nanomodified CFA-WBP (class $\mathrm{C}$ fly ash-waste brick powder) based geopolymers. Cem Concr Compos 2017;79:53-61. https://doi.org/10.1016/j.cemconcomp.2017.01.007.

50. Myers RJ, L'Hôpital E, Provis JL, Lothenbach B. Effect of temperature and aluminium on calcium (alumino)silicate hydrate chemistry under equilibrium conditions. Cem Concr Res 2015;68:83-93. https://doi.org/10.1016/j.cemconres.2014.10.015.

51. Wattanachai P, Suwan T. Strength of Geopolymer Cement Curing at Ambient Temperature by NonOven Curing Approaches: An Overview. IOP Conf Ser Mater Sci Eng 2017;212. https://doi.org/10.1088/1757-899X/212/1/012014.

\section{Figures}




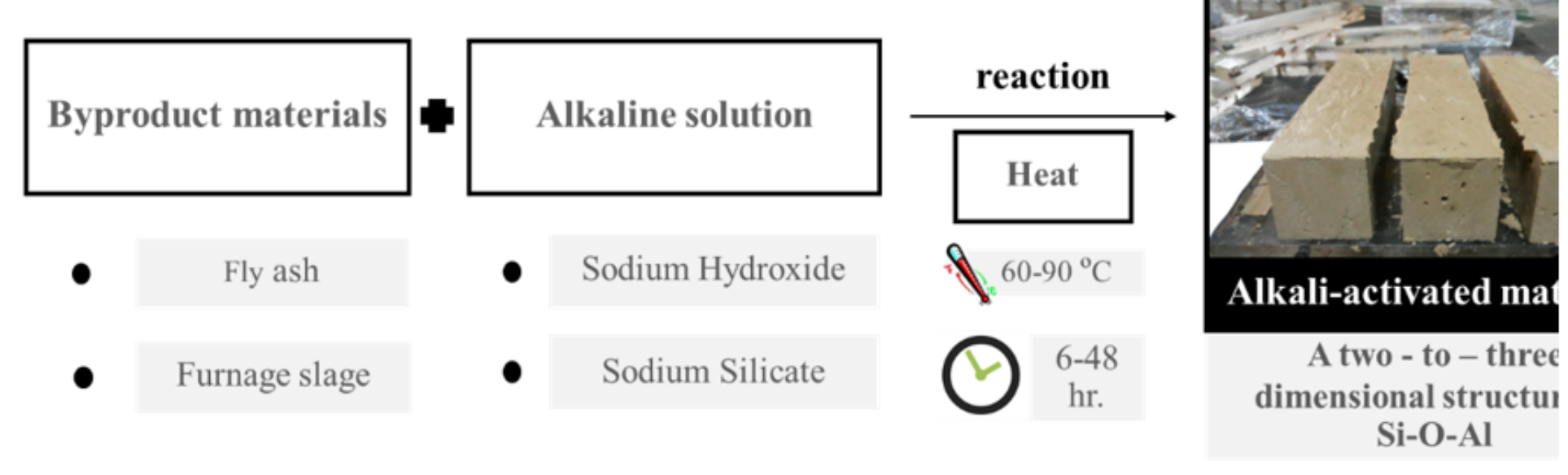

\section{Figure 1}

A typical process to synthesize alkali-activated materials

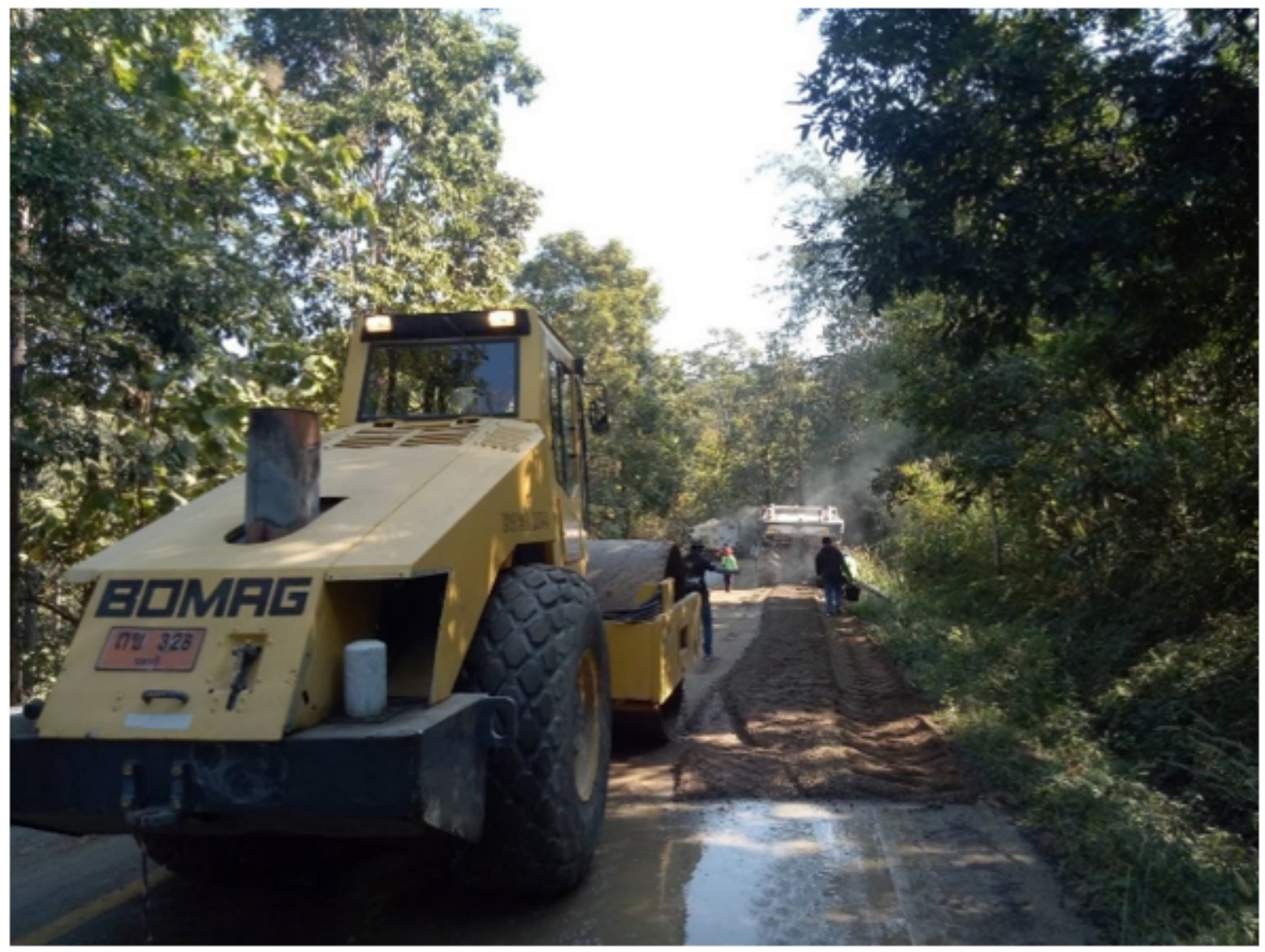

Figure 2

Possible application using AAM for in-situ pavement recycling 


\section{Crushed rock}

- Crushing the rock to the fine grain

- Gliding through the sieve number 100

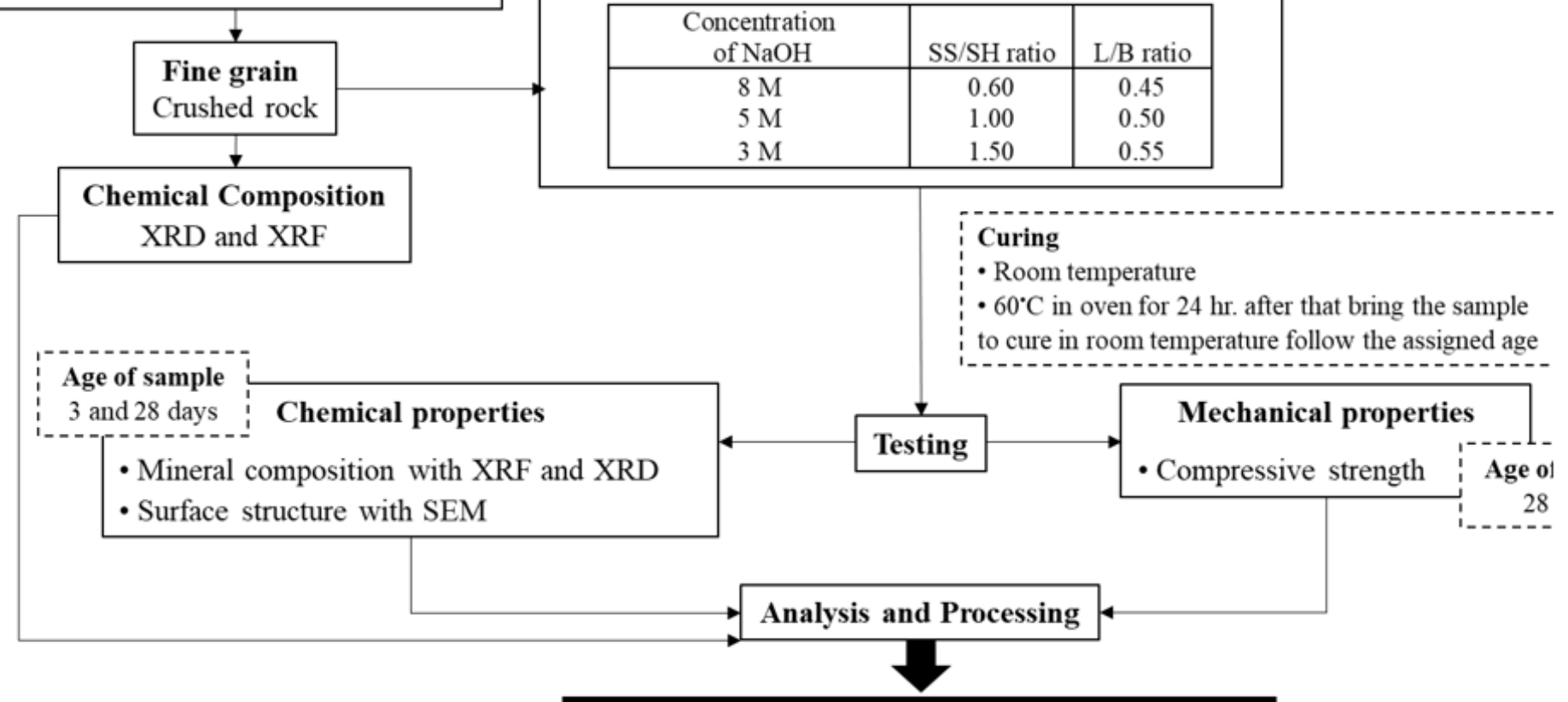

Crushed rock-base alkali-activated material

Figure 3

Research framework and methodology
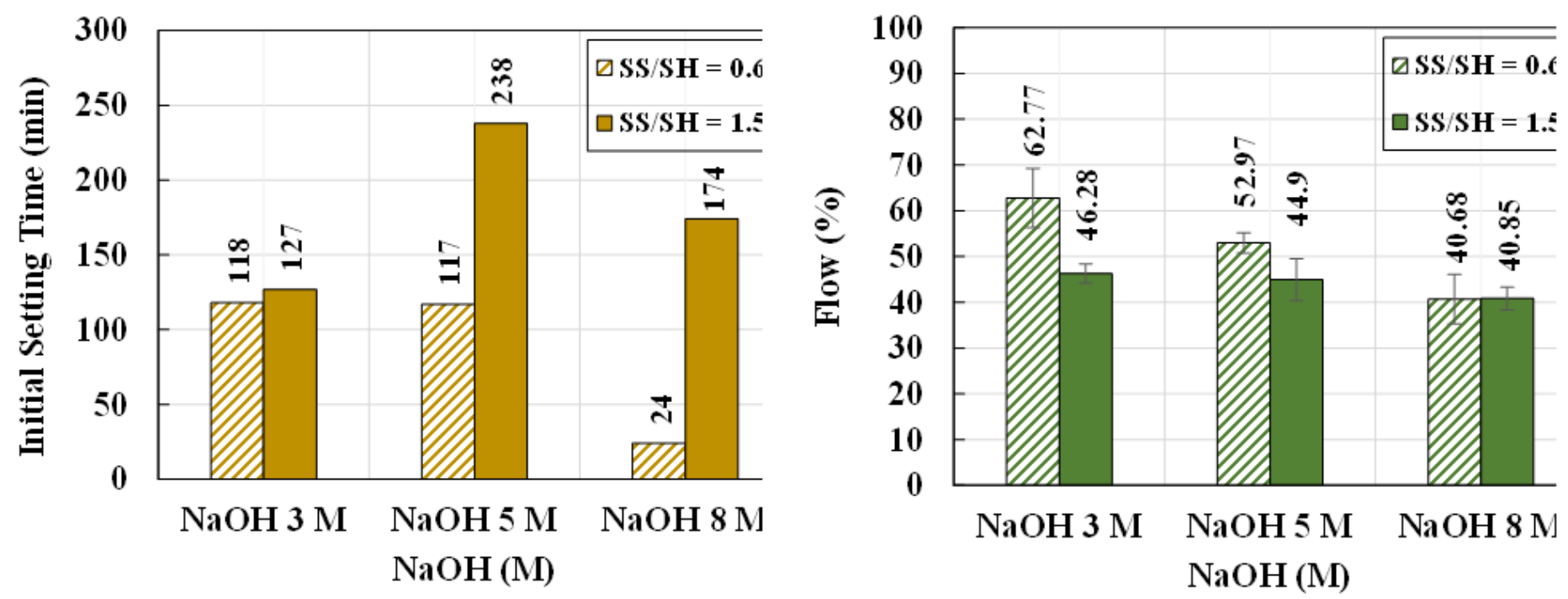

Figure 4

Setting times and flow values of various $\mathrm{NaOH}$ concentrations and $\mathrm{SS} / \mathrm{SH}$ ratios 


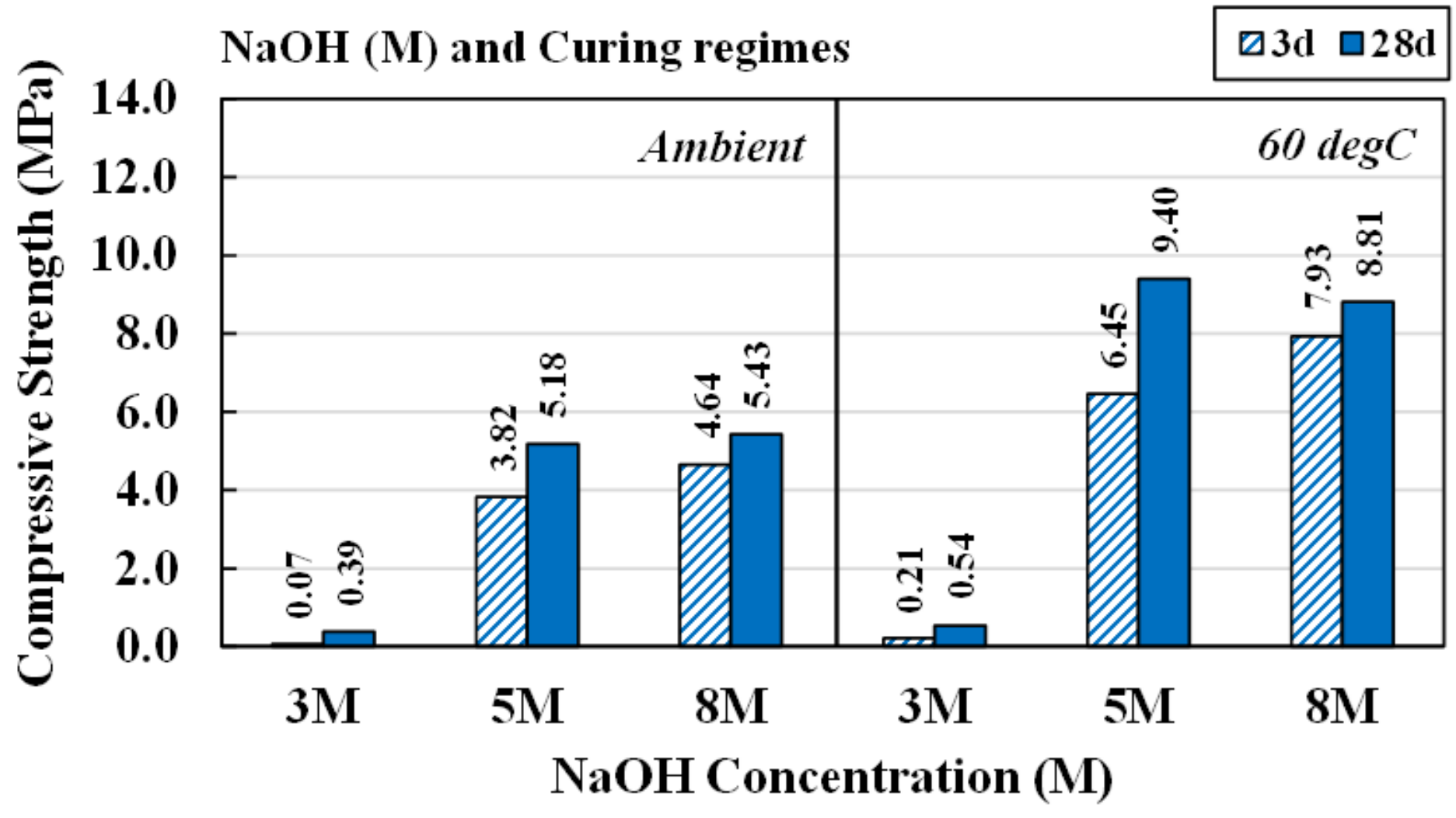

Figure 5

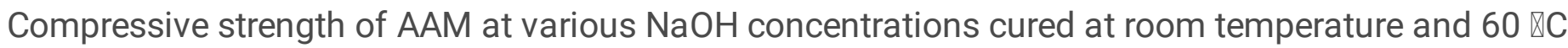

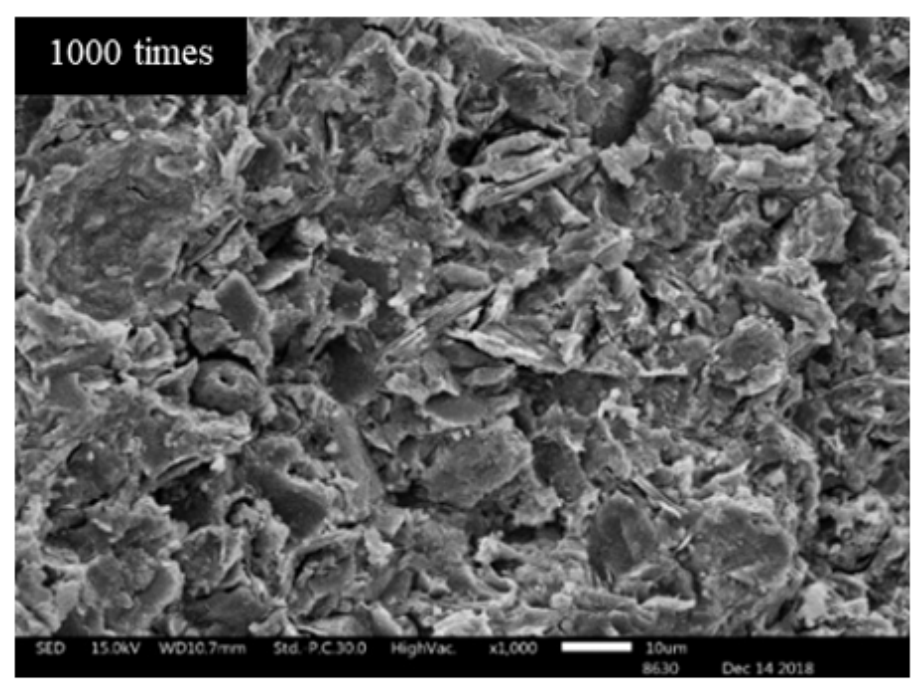

(a) Cured at room temperature

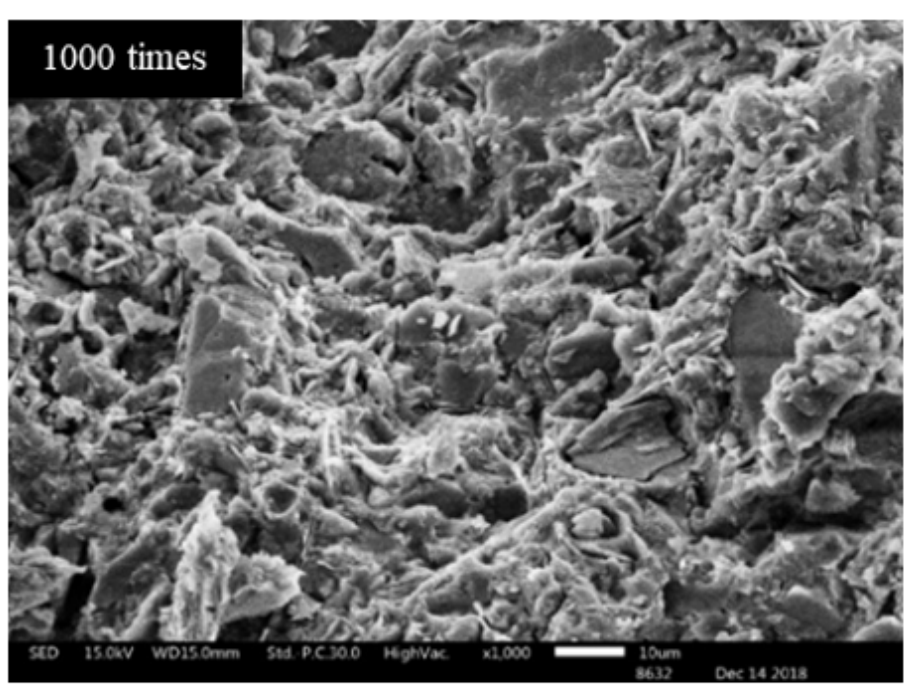

(b) Cured in the oven at $60{ }^{\circ} \mathrm{C}$

Figure 6

SEM images of the AAM preparing with $5 \mathrm{M} \mathrm{NaOH}$ at 28 days (a) Cured at room temperature and (b) Cured in the oven at $60 \otimes C$ 

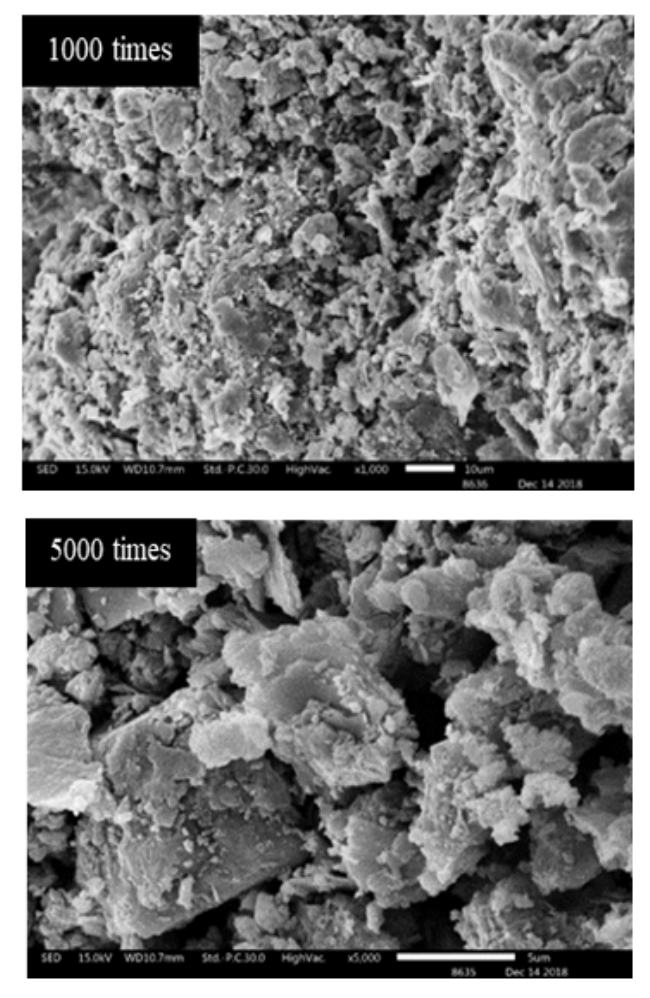

(a) $3 \mathrm{M} \mathrm{NaOH}$
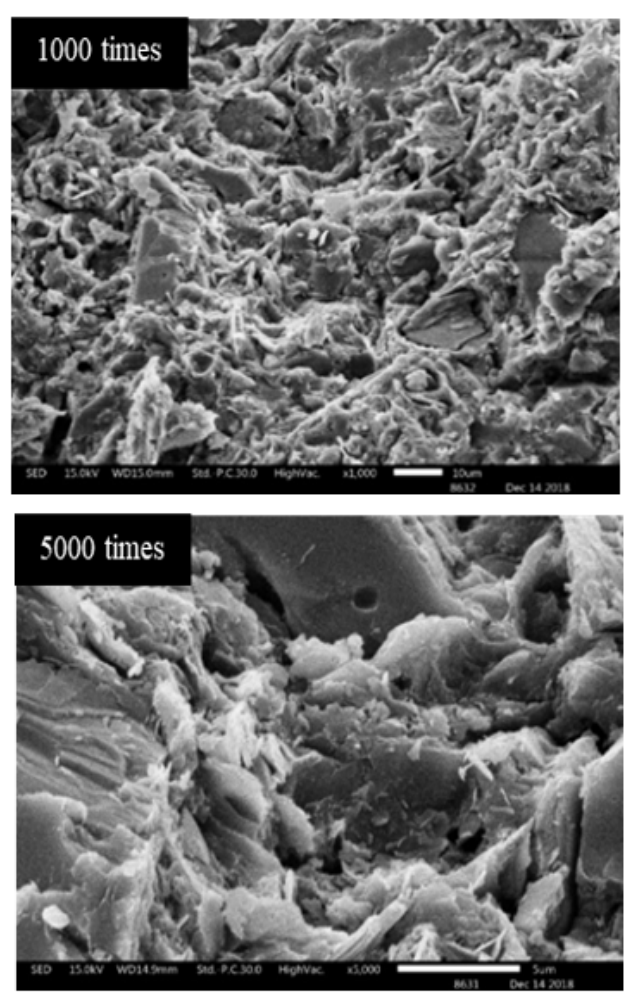

(b) $5 \mathrm{M} \mathrm{NaOH}$
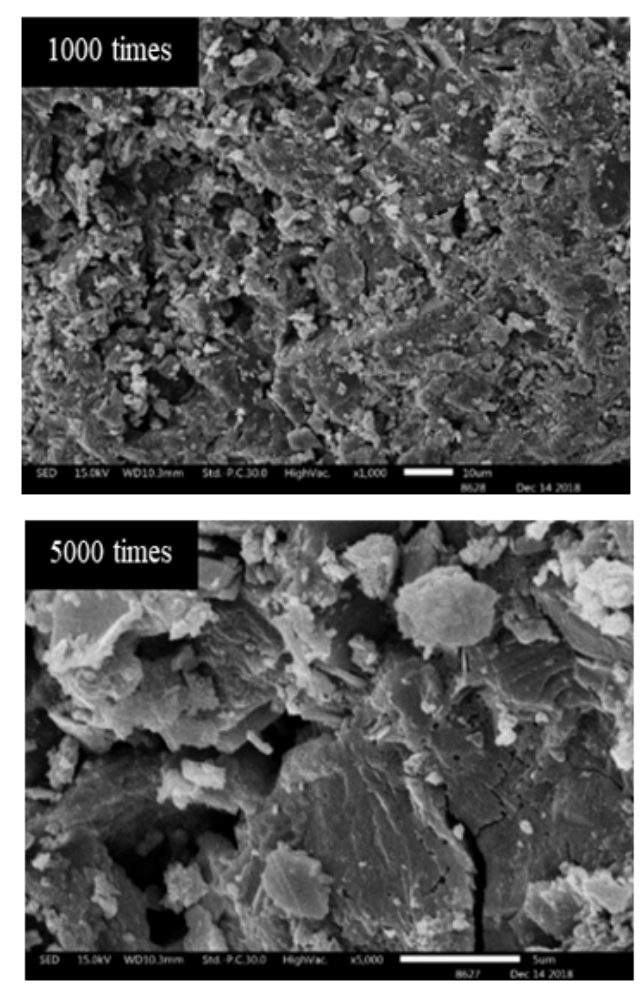

(c) $8 \mathrm{M} \mathrm{NaOH}$

Figure 7

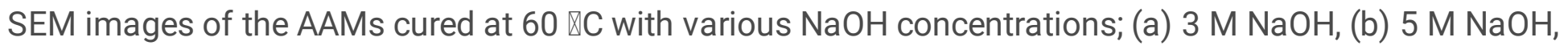
and (c) $8 \mathrm{M} \mathrm{NaOH}$

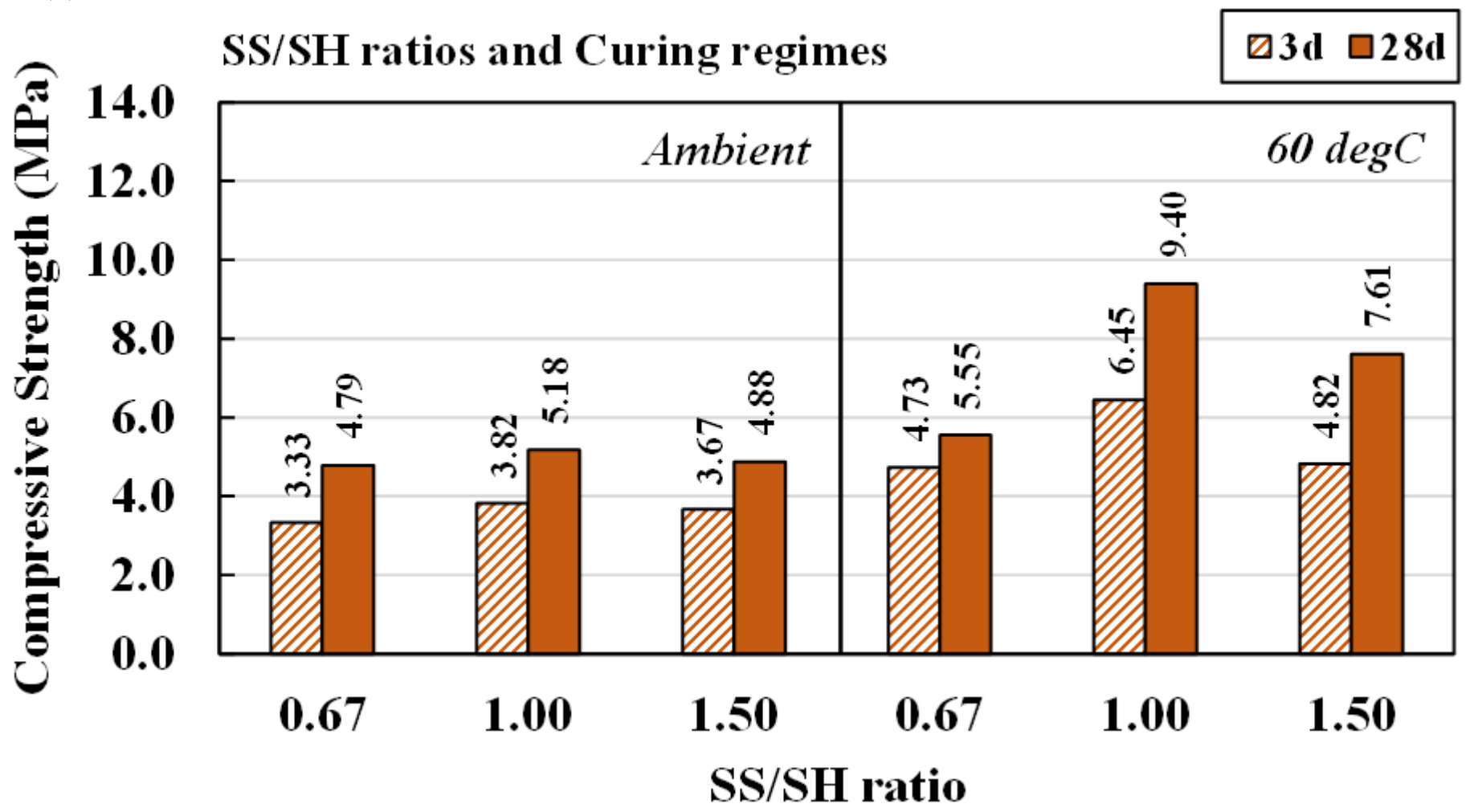


Figure 8

Compressive strength of AAM preparing with $5 \mathrm{M} \mathrm{NaOH}$ at various SS/SH ratios

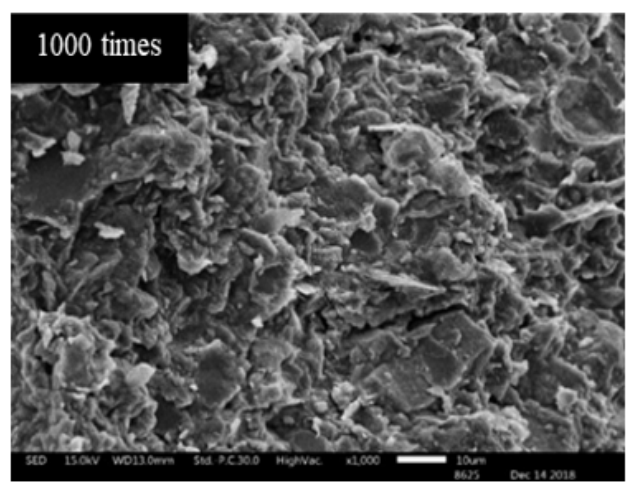

(a) $\mathrm{SS} / \mathrm{SH}=0.67$

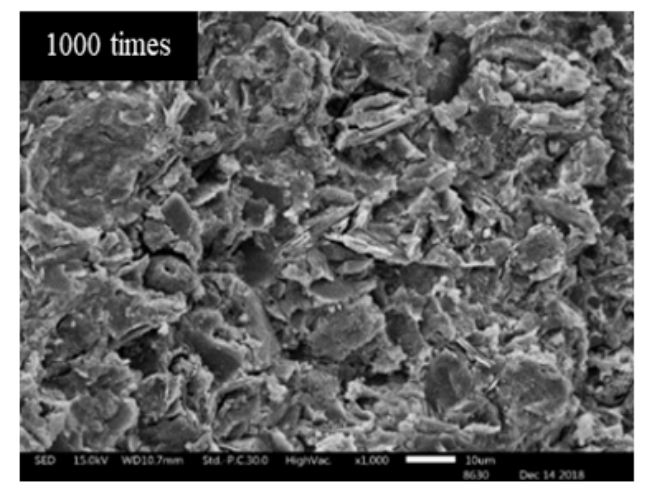

(b) $\mathrm{SS} / \mathrm{SH}=1.00$

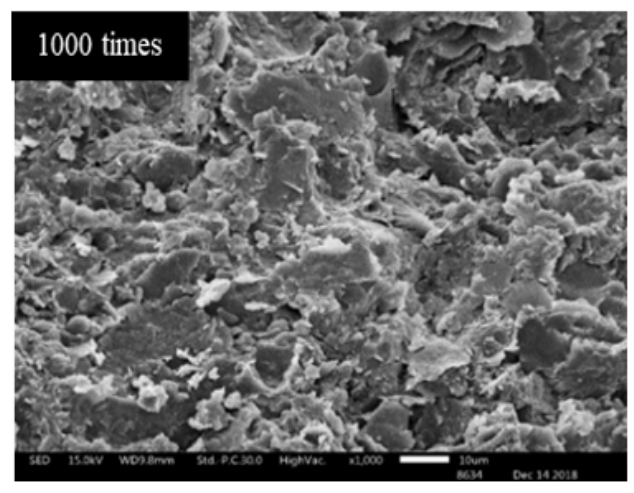

(c) $\mathrm{SS} / \mathrm{SH}=1.50$

Figure 9

SEM images of the mixtures cured at room temperature with $5 \mathrm{M} \mathrm{NaOH}$, an $\mathrm{L} / \mathrm{B}$ ratio of 0.50 , and various $\mathrm{SS} / \mathrm{SH}$ ratios; (a) $\mathrm{SS} / \mathrm{SH}=0.67$, (b) $\mathrm{SS} / \mathrm{SH}=1.00$, and (c) $\mathrm{SS} / \mathrm{SH}=1.50$

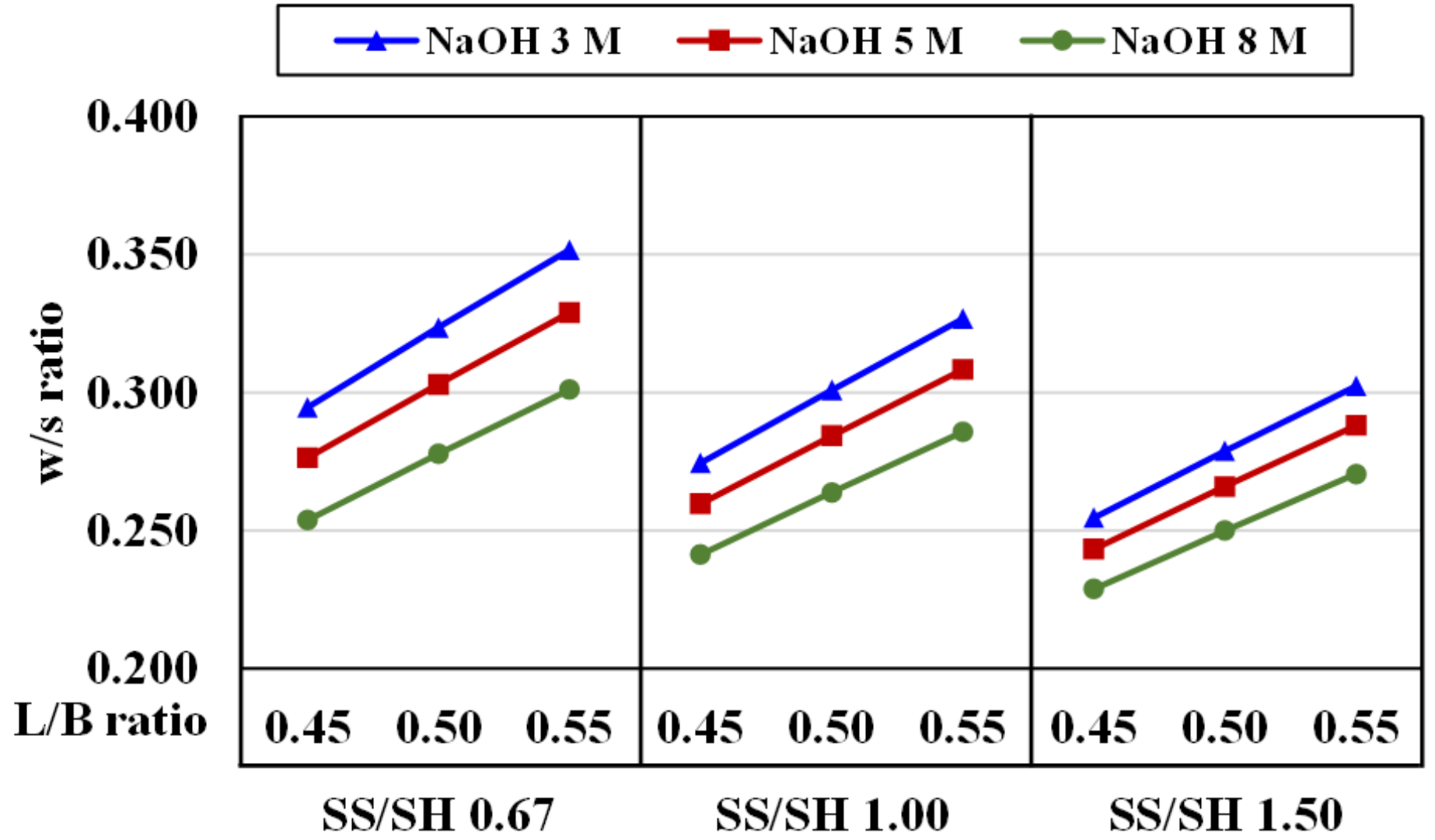

Figure 10

Water-to-solid (w/s) ratios compared to liquid alkaline-to-binder (L/B) ratios in CR-AAM systems 


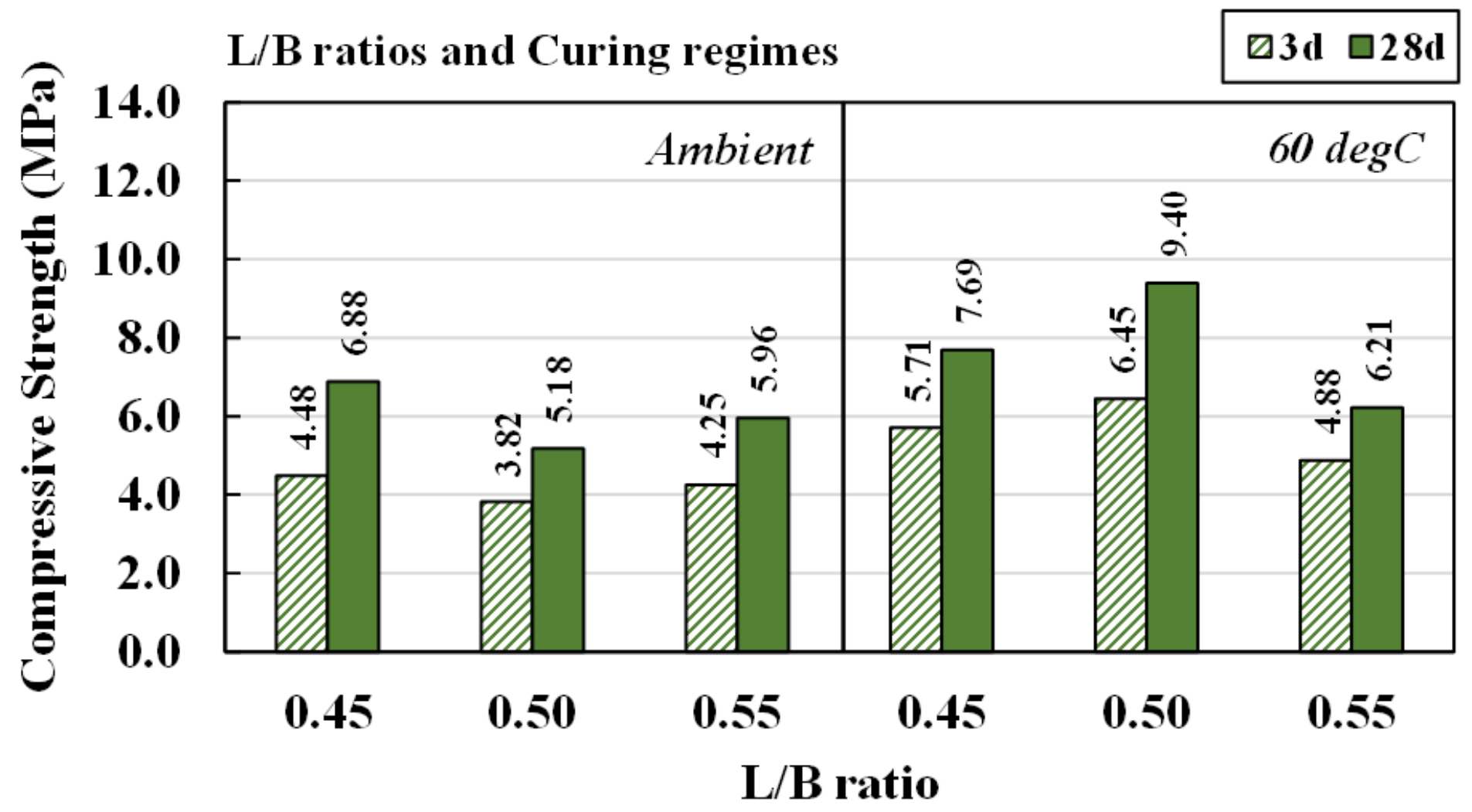

Figure 11

Compressive strength of mixtures at various $\mathrm{L} / \mathrm{B}$ ratios cured at room temperature and at $60 \bowtie \mathrm{C}$ 


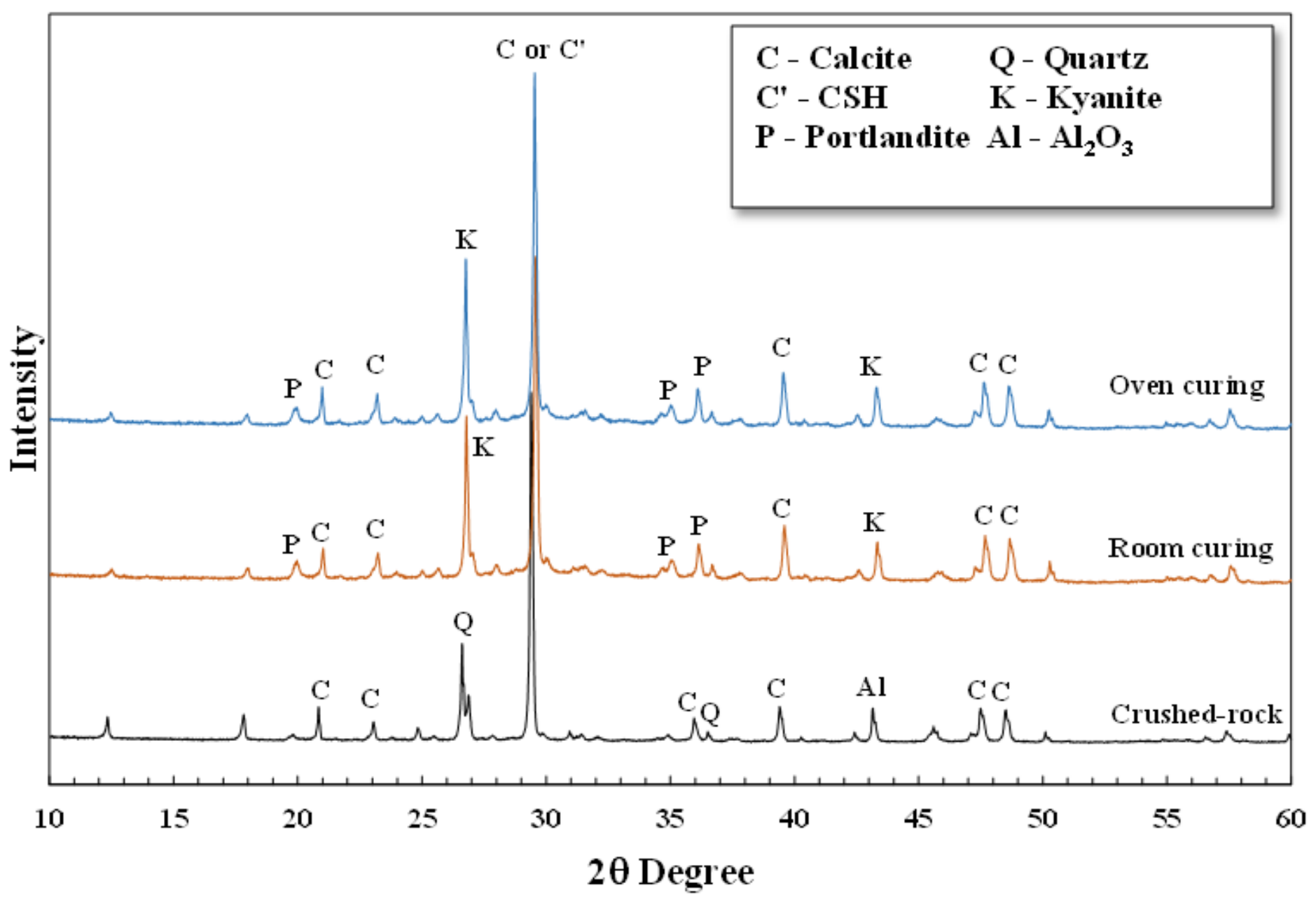

Figure 12

XRD patterns of original $\mathrm{CR}$ and $\mathrm{AAM}$ preparing with $5 \mathrm{M} \mathrm{NaOH}$ at 28 days 


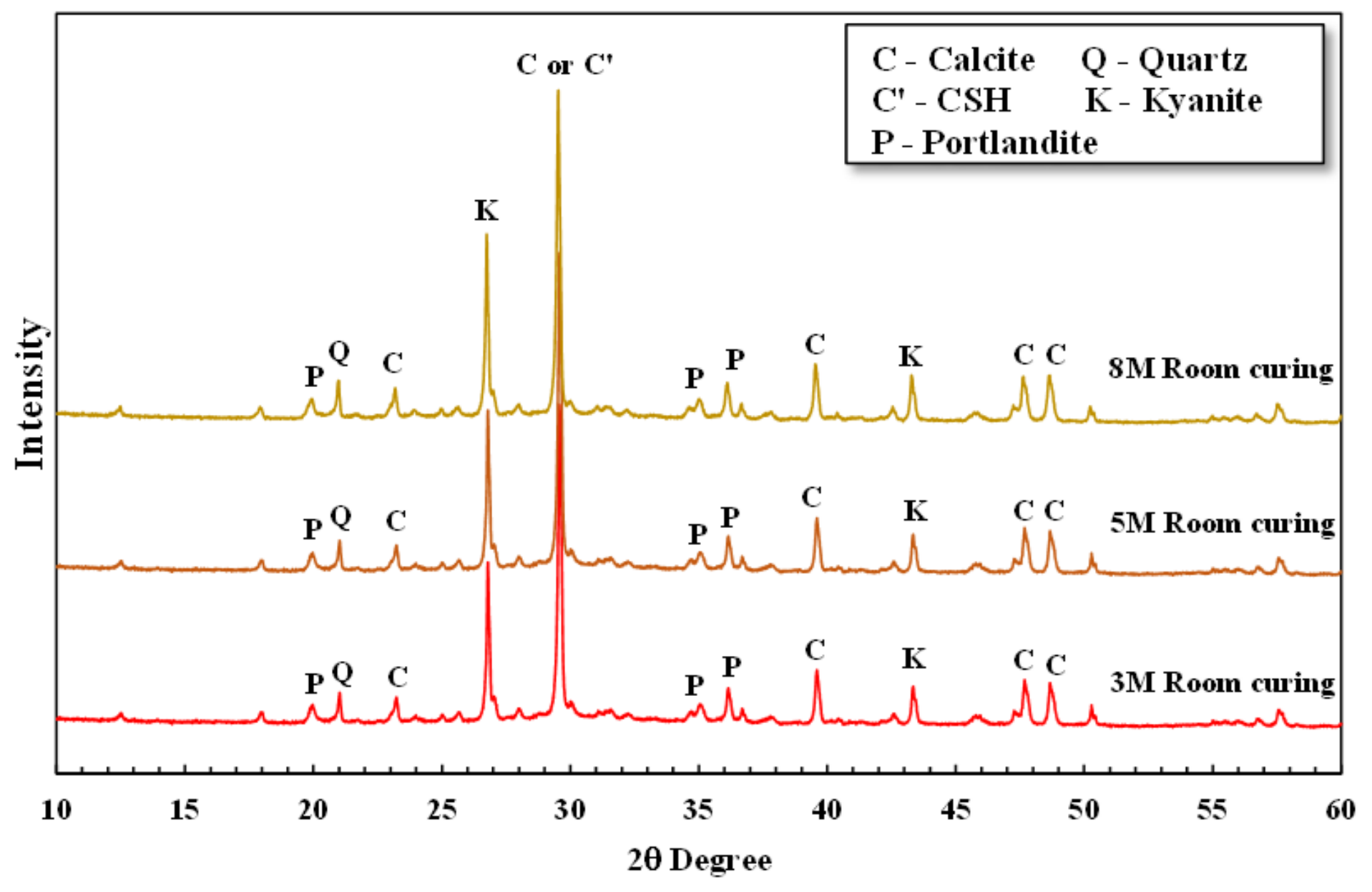

Figure 13

XRD patterns of AAM with various $\mathrm{NaOH}$ concentrations cured at room temperature 


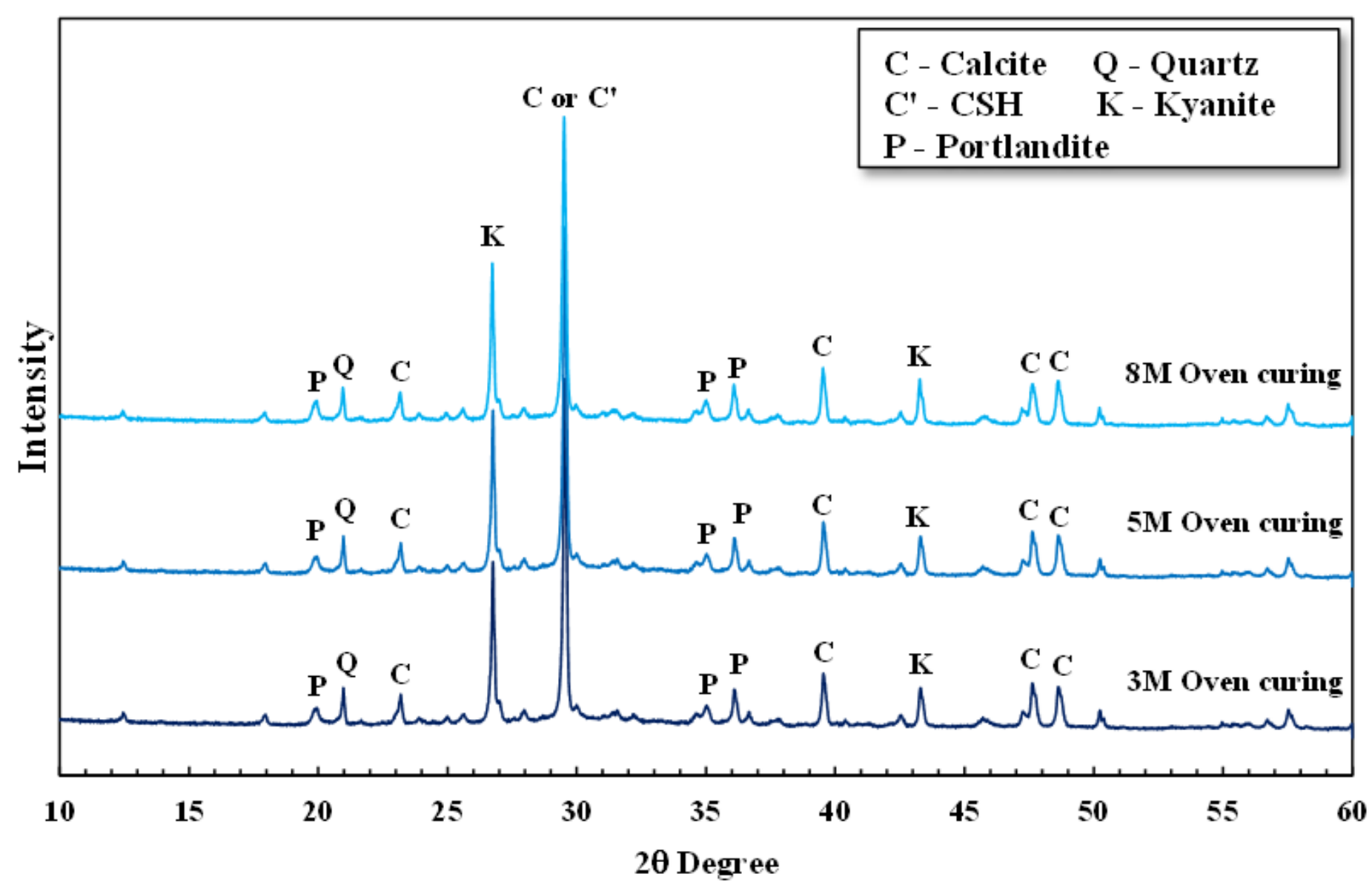

Figure 14

XRD patterns of AAM with various $\mathrm{NaOH}$ concentrations cured in oven 